\title{
Modeling the Costs of Hospital-AcQuired INFECTIONS IN NEW ZEALAND
}

\author{
Nicholas Graves, $\mathrm{PhD}$; Tanya M. Nicholls, NZRCpN, DPH, CIC; Arthur J. Morris, MD, DipABMM
}

\begin{abstract}
OBJECTIVE: To model the economic costs of hospitalacquired infections (HAIs) in New Zealand, by type of HAI.

DESIGN: Monte Carlo simulation model.

SETTING: Auckland District Health Board Hospitals (DHBH), the largest publicly funded hospital group in New Zealand supplying secondary and tertiary services. Costs are also estimated for predicted HAIs in admissions to all hospitals in New Zealand.

PATIENTS: All adults admitted to general medical and general surgical services.

METHOD: Data on the number of cases of HAI were combined with data on the estimated prolongation of hospital stay due to HAI to produce an estimate of the number of bed days attributable to HAI. A cost per bed day value was applied to provide an estimate of the economic cost. Costs were estimated for predicted infections of the urinary tract, surgical wounds, the lower and

upper respiratory tracts, the bloodstream, and other sites, and for cases of multiple sites of infection. Sensitivity analyses were undertaken for input variables.

RESULTS: The estimated costs of predicted HAIs in medical and surgical admissions to Auckland DHBH were $\$ 10.12$ (US $\$ 4.56$ ) million and $\$ 8.64$ (US $\$ 3.90$ ) million, respectively. They were $\$ 51.35$ (US $\$ 23.16$ ) million and $\$ 85.26$ (US $\$ 38.47$ ) million, respectively, for medical and surgical admissions to all hospitals in New Zealand.

CONCLUSIONS: The method used produces results that are less precise than those of a specifically designed study using primary data collection, but has been applied at a lower cost. The estimated cost of HAIs is substantial, but only a proportion of infections can be avoided. Further work is required to identify the most cost-effective strategies for the prevention of HAI (Infect Control Hosp Epidemiol 2003;24:214-223).
\end{abstract}

Studies of the economic cost of hospital-acquired infection have been undertaken in the United States, ${ }^{1-15}$ England, ${ }^{16-21}$ Germany, ${ }^{22,23}$ Denmark, ${ }^{24}$ Spain, ${ }^{25,26}$ China, ${ }^{27}$ Israel, ${ }^{28}$ and France. ${ }^{29}$ The findings illustrate the impact of the disease on the acute and the community healthcare sectors, patients, caregivers, and the wider economy. These data have been used to raise the profile of hospital-acquired infection among policy makers ${ }^{30}$ and, if appropriately derived, they proxy the value of the potential economic benefits that result from programs that prevent hospitalacquired infection. ${ }^{31}$

Although the prevalence of hospital-acquired infections in New Zealand hospitals and estimates of the cumulative incidence have been reported, ${ }^{32,33}$ no estimates of the economic cost of these infections have been published. The purpose of this article is to model the cost attributable to hospital-acquired infections occurring among adult patients admitted to the general medical and surgical services of Auckland District Health Board
Hospitals for calendar year 1999 and patients admitted to all hospitals in New Zealand for the 1998-1999 financial year.

The cost analysis includes only hospital costs because recent work has shown that $93.4 \%$ of the total costs of hospital-acquired infection fall on the hospital sector ${ }^{34}$ and assessing the remaining costs, those that fall on primary and community care services and the patients themselves, would involve extensive additional data collection and analysis. The method uses data gathered from the routine surveillance of hospital-acquired infection in Auckland District Health Board Hospitals, ${ }^{32}$ estimates of the cumulative incidence derived from these data, ${ }^{33}$ and findings from the published literature.

\section{METHODS}

Setting

Auckland District Health Board Hospitals comprises four separate hospitals. Auckland Hospital has 560 beds and

Dr. Graves is from the Centre for Health Care Related Infection Surveillance and Prevention, Princess Alexandra Hospital, and the School of Public Health, Queensland University of Technology, Queensland, Australia. Ms. Nicholls is from the Auckland District Health Board; and Dr. Morris is from the Auckland District Health Board, Infection Control Service, Auckland, New Zealand.

Address reprint requests to Dr. Nicholas Graves, School of Public Health, QUT, Victoria Park Road, Kelvin Grove, QLD, 4059, Australia.

For the conduct of this research, Nicholas Graves was on academic sabbatical from the London School of Hygiene \& Tropical Medicine at the Department of Community Health, University of Auckland, New Zealand.

Supported by the NHS Executive, London, R\&D Training and Development Programme. 
provides emergency, acute, and elective general medical and surgical services, as well as major hematology, oncology, and liver transplant services. Green Lane Hospital has 197 beds and provides otorhinolaryngology, cardiology, respiratory medicine, and cardiothoracic surgery services, including heart and lung transplants. National Women's Hospital provides maternity and neonatal intensive care services, and Starship Hospital is a specialist pediatrics hospital; admissions to the National Women's and Starship hospitals were excluded from this study.

In 1999, there were 32,179 medical and 24,899 surgical admissions for Auckland and Green Lane hospitals with an average length of stay of 4.7 and 5.2 days, respectively. Existing infection control services include four dedicated infection control practitioners and a service coordinator. They are supported by infectious disease physicians or microbiologists, who supply 1 day per week to the service ( 0.2 full-time equivalent). The approximate cost of these services, including staff time, expenses, overhead, and education, is $\$ 450,000$ (US $\$ 203,032$ ) per year. In addition to the routine infection control activities, point-prevalence surveys are performed twice a year by two-person teams consisting of a physician and an infection control practitioner. ${ }^{32,33}$ All patients except pediatric cases in Starship Hospital are included.

\section{Overview of the Method}

Data on the predicted number of cases of hospitalacquired infection were combined with data on the estimated prolongation of stay due to hospital-acquired infection. This produced an estimate of the number of bed days attributable to hospital-acquired infection. Valuations of the opportunity cost of the resources used to supply a bed day were applied to derive a monetary estimate of the opportunity cost of hospital-acquired infection. This method is detailed in Table 1.

The patient population is all adults admitted to general medical and surgical services and cost estimates are derived for the following single sites of hospital-acquired infection: surgical wound (SW), lower and upper respiratory tracts (CHEST), urinary tract (UT), bloodstream (BS), and other sites (OTHER). Cost estimates are also derived for patients with more than one site of hospital-acquired infection (MULTI).

\section{Data Sources}

Estimates of the cumulative incidence of hospitalacquired infection in medical and surgical admissions to Auckland District Health Board Hospitals are presented in Table $2{ }^{33}$ These rates, and the values for the $95 \%$ confidence intervals, were applied to the 32,179 medical and 24,899 surgical admissions to Auckland District Health Board Hospitals and to the 162,879 medical and 245,130 surgical admissions to all acute hospitals in New Zealand in 1999 to derive an estimate of the "most likely," "low," and "high" number of cases of hospital-acquired infection. The results of this are presented in Table 2 and provide the information required for category A of Table 1.
TABLE 1

OverVieW OF THE Method Used to Determine the Cost Of HOSPITAL-ACQUTRED INFECTION IN NEW ZEALAND

A Number of cases of hospital-acquired infection (with esti-
mates of likely variation)
B Additional bed days per case (with estimates of likely vari-
ation)
C Opportunity cost per bed days (point estimate)
Cost of hospital-acquired infection $=\mathrm{A}^{\star} \mathrm{B}^{\star} \mathrm{C}$

To determine estimates of the likely prolongation of length of stay due to hospital-acquired infection, the published literature was reviewed. An electronic search was made of the MEDLINE database. ${ }^{35}$ Searches were made for the subject heading "cross infection" and then the subheading "economics"; this search yielded 418 articles. These results were combined with the results of a further search of the key word(s) "length of stay"; this yielded 106 articles. These abstracts were reviewed and all articles that included a specific investigation of the prolongation of hospital stay due to hospital-acquired infection were retrieved. Foreign language articles that did not report the results in the English abstract were discarded. Articles that reported results only by pathogen and not by site or specialty were discarded. The reference lists of the remaining articles. were reviewed so that any further relevant articles might be identified. The following information was extracted from the final set of articles: site of hospital-acquired infection studied; patient group studied; number of patients with hospital-acquired infection included in the analysis; study design; year of publication; country in which the study was undertaken; and prolongation of hospital stay due to hospital-acquired infection. The results of this process are presented in the Appendix. Studies published before 1980 were excluded to reduce bias arising from changes to length of stay, treatment regimens, and clinical practice that would inevitably have occurred over time.

The values of the prolongation of length of stay derived from the literature were applied to the model as follows: values reported for "all admissions" were used to indicate the likely prolongation of length stay for the predicted cases of hospital-acquired infection in medical admissions in the model; values reported for "surgical patients" were used for the predicted cases of hospital-acquired infection in surgical admissions in the model; and, because no values were reported in the literature for CHEST, BS, and OTHER in "surgical patients," the values for "all admissions" were applied. The number of values for the estimated prolongation of hospital stays for each type of hospital-acquired infection was insufficient to allow any useful inferences to be made about the nature of the probability distribution. Instead, the "low," "median," and "high" values for prolongation of hospital stay due to hospital-acquired infection were used for each type of hospital-acquired infection. These data, and the references to the articles from which 


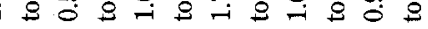

they were drawn, are presented in Table 2 and provide the information required for category $B$ in Table 1 .

The corporate accounts department of the study hospital derived the cost of the resources used to supply a bed day. The operating costs of the organization reflect the market prices paid for the labor, consumables, and utilities and include a valuation for the use of capital infrastructure. The estimated 1999 cost per bed day for medical and surgical admissions was $\$ 557$ (US \$251). In addition, a low value of $\$ 279$ (US $\$ 126$ ), $50 \%$ of the estimate, and a high value of $\$ 836$ (US $\$ 377$ ), $150 \%$ of the estimate, were used in the modeling. This provides the information required for category $\mathrm{C}$ in Table 1.

\section{Data Analysis}

To model the effect of uncertainty around the input variables on the outcome variable, cost of hospital-acquired infection, Monte Carlo simulation was applied using risk assessment software. ${ }^{35}$ This technique combines the uncertainties around the input variables and produces a range of output values that reflect these uncertainties. To run these models, assumptions are required about the probability distribution of values for the input variable.

Uncertainty for the number of cases was described by the "low," "likely," and "high" values for number of cases. These three data points were triangulated, based on the assumption that the "likely" value had a greater probability of occurring than did the "high" and "low" values, which had the same probability of occurring, and used as the starting point for the simulation. Uncertainty for the prolongation of length of stay was based on the results from the review of the literature (Appendix). The "low," "median," and "high" estimates for each site of hospitalacquired infection, and for multiple sites, were assumed to reflect the "low," "likely," and "high" values, triangulated as above and used as the starting point for the simulation. Because the cost per bed day data were calculated from known local data, point estimates of cost were used in the model. However, to allow different scenarios to be examined, the model was simulated for "low," "estimated," and "high" values of the cost of a bed day.

Because the direction of causation in the model was unambiguous, a sensitivity analysis was conducted by a multivariate stepwise regression in which the sampled input variable values were regressed against output values, leading to a coefficient of sensitivity for each input variable. This coefficient is an estimate of the independent change in the output variable due to a unit change in the input variable.

\section{RESULTS}

The values for the input variables used in the simulation models for medical and surgical patients are presented in Table 2. The results of the simulation model for admissions to Auckland District Health Board Hospitals are presented in Table 3.

The total costs for predicted infections in medical patients assuming \$279 (US \$126) per bed day, \$557 (US 
TABLE 3

Mean Cost of Hospital-Acquired Infection in Admissions to Auckland District Heaith Board Hospitals: Results of Simulation Models for the Three Different Values of a Bed Day

\begin{tabular}{|c|c|c|c|c|c|c|}
\hline \multirow{2}{*}{$\begin{array}{l}\text { Hospital- } \\
\text { Acquired } \\
\text { Infection }\end{array}$} & \multicolumn{2}{|c|}{ Low Value of Bed Day (Range) } & \multicolumn{2}{|c|}{ Estimated Value for Bed Day (Range) } & \multicolumn{2}{|c|}{ High Value for Bed Day (Range) } \\
\hline & Medical & Surglcal & Medical & Surglical & Medical & Surgical \\
\hline \multicolumn{7}{|l|}{ UT } \\
\hline $\mathrm{NZS}$ & $\begin{array}{l}273,964(94,081 \\
\text { to } 547,831)\end{array}$ & $\begin{array}{l}789,046(649,062 \\
\text { to } 907,446)\end{array}$ & $\begin{array}{l}548,967(179,555 \\
\text { to } 1,123,388)\end{array}$ & $\begin{array}{l}1,572,834(1,325,539 \\
\text { to } 1,821,362)\end{array}$ & $\begin{array}{l}834,917(281,167 \\
\text { to } 1,692,315)\end{array}$ & $\begin{array}{l}2,363,826(1,973,031 \\
\text { to } 2,727,774)\end{array}$ \\
\hline US\$ & $\begin{array}{l}123,608(42,448 \\
\text { to } 247,172)\end{array}$ & $\begin{array}{l}356,004(292,846 \\
\text { to } 409,424)\end{array}$ & $\begin{array}{l}247,685(81,012 \\
\text { to } 506,854)\end{array}$ & $\begin{array}{l}709,637(598,061 \\
\text { to } 821,768)\end{array}$ & $\begin{array}{l}376,701(126,858 \\
\text { to } 763,545)\end{array}$ & $\begin{array}{l}1,066,519(890,199 \\
\text { to } 1,230,726)\end{array}$ \\
\hline \multicolumn{7}{|l|}{ SW } \\
\hline $\mathrm{NZS}$ & $\begin{array}{l}349,833(131,351 \\
\text { to } 638,268)\end{array}$ & $\begin{array}{l}1,608,821(1,055,381 \\
\text { to } 2,078,332)\end{array}$ & $\begin{array}{l}710,456(253,310 \\
\text { to } 1,228,640)\end{array}$ & $\begin{array}{l}3,249,936(2,123,207 \\
\text { to } 4,192,093)\end{array}$ & $\begin{array}{l}1,033,967(378,005 \\
\text { to } 1,871,999)\end{array}$ & $\begin{array}{l}4,907,425(3,200,530 \\
\text { to } 6,270,669)\end{array}$ \\
\hline US\$ & $\begin{array}{l}157,839(59,263 \\
\text { to } 287,976)\end{array}$ & $\begin{array}{l}725,873(476,170 \\
\text { to } 937,709)\end{array}$ & $\begin{array}{l}320,546(114,289 \\
\text { to } 554,342)\end{array}$ & $\begin{array}{l}1,466,317(957,956 \\
\text { to } 1,891,403)\end{array}$ & $\begin{array}{l}466,509(170,550 \\
\text { to } 844,615)\end{array}$ & $\begin{array}{l}2,214,149(1,444,026 \\
\text { to } 2,829,222)\end{array}$ \\
\hline \multicolumn{7}{|l|}{ CHEST } \\
\hline $\mathrm{NZS}$ & $\begin{array}{l}586,248(333,090 \\
\text { to } 883,542)\end{array}$ & $\begin{array}{l}432,645(259,769 \\
\text { to } 646,311)\end{array}$ & $\begin{array}{l}1,191,409(658,980 \\
\text { to } 1,808,564)\end{array}$ & $\begin{array}{l}882,000(520,693 \\
\text { to } 1,281,427)\end{array}$ & $\begin{array}{l}1,757,516(996,935 \\
\text { to } 2,694,121)\end{array}$ & $\begin{array}{l}1,304,541(782,406 \\
\text { to } 1,915,580)\end{array}$ \\
\hline US\$ & $\begin{array}{l}264,505(150,285 \\
\text { to } 398,639)\end{array}$ & $\begin{array}{l}195,202(117,203 \\
\text { to } 291,605)\end{array}$ & $\begin{array}{l}537,544(297,321 \\
\text { to } 815,994)\end{array}$ & $\begin{array}{l}397,944(234,928 \\
\text { to } 578,159)\end{array}$ & $\begin{array}{l}792,962(449,800 \\
\text { to } 1,215,543)\end{array}$ & $\begin{array}{l}588,587(353,009 \\
\text { to } 864,278)\end{array}$ \\
\hline \multicolumn{7}{|l|}{ BS } \\
\hline NZS & $\begin{array}{l}840,700(198,417 \\
\text { to } 1,649,030)\end{array}$ & $\begin{array}{l}173,353(25,637 \\
\text { to } 443,088)\end{array}$ & $\begin{array}{l}1,673,121(374,954 \\
\text { to } 3,233,980)\end{array}$ & $\begin{array}{l}355,965(58,221 \\
\text { to } 823,227)\end{array}$ & $\begin{array}{l}2,543,310(520,512 \\
\text { to } 4,982,466)\end{array}$ & $\begin{array}{l}539,124(91,429 \\
\text { to } 1,266,393)\end{array}$ \\
\hline US\$ & $\begin{array}{l}379,310(89,522 \\
\text { to } 744,015)\end{array}$ & $\begin{array}{l}78,214(11,567 \\
\text { to } 199,914)\end{array}$ & $\begin{array}{l}754,884(169,173 \\
\text { to } 1,459,118)\end{array}$ & $\begin{array}{l}160,605(26,268 \\
\text { to } 371,427)\end{array}$ & $\begin{array}{l}1,147,499(234,846 \\
\text { to } 2,248,006)\end{array}$ & $\begin{array}{l}243,244(41,251 \\
\text { to } 571,376)\end{array}$ \\
\hline \multicolumn{7}{|l|}{ OTHER } \\
\hline $\mathrm{NZS}$ & $\begin{array}{l}450,642(75,404 \\
\text { to } 986,137)\end{array}$ & $\begin{array}{l}298,431(51,773 \\
\text { to } 711,850)\end{array}$ & $\begin{array}{l}852,287(149,457 \\
\text { to } 1,930,430)\end{array}$ & $\begin{array}{l}615,556(100,795 \\
\text { to } 1,349,892)\end{array}$ & $\begin{array}{l}1,324,365(237,297 \\
\text { to } 2,953,250)\end{array}$ & $\begin{array}{l}916,210(169,533 \\
\text { to } 2,057,015)\end{array}$ \\
\hline US\$ & $\begin{array}{l}203,322(34,021 \\
\text { to } 444,929)\end{array}$ & $\begin{array}{l}134,647(23,359 \\
\text { to } 321,175)\end{array}$ & $\begin{array}{l}384,538(67,433 \\
\text { to } 870,978)\end{array}$ & $\begin{array}{l}277,729(45,477 \\
\text { to } 609,049)\end{array}$ & $\begin{array}{l}597,532(107,065 \\
\text { to } 1,332,458)\end{array}$ & $\begin{array}{l}413,379(76,490 \\
\text { to } 928,091)\end{array}$ \\
\hline \multicolumn{7}{|l|}{ MULTI } \\
\hline NZS & $\begin{array}{l}2,596,854(1,687,451 \\
\text { to } 3,465,328)\end{array}$ & $\begin{array}{l}994,837(457,536 \\
\text { to } 1,527,699)\end{array}$ & $\begin{array}{l}5,152,621(3,413,563 \\
\text { to } 6,956,884)\end{array}$ & $\begin{array}{l}1,969,899(958,471 \\
\text { to } 3,015,736)\end{array}$ & $\begin{array}{l}7,724,299(5,107,130 \\
\text { to } 10,353,960)\end{array}$ & $\begin{array}{l}2,897,134(1,346,798 \\
\text { to } 4,540,990)\end{array}$ \\
\hline US\$ & $\begin{array}{l}1,171,658(761,350 \\
\text { to } 1,563,499)\end{array}$ & $\begin{array}{l}448,854(206,433 \\
\text { to } 689,272)\end{array}$ & $\begin{array}{l}2,324,777(1,540,143 \\
\text { to } 3,138,831)\end{array}$ & $\begin{array}{l}888,786(432,446 \\
\text { to } 1,360,650)\end{array}$ & $\begin{array}{l}3,485,076(2,304,252 \\
\text { to } 4,671,535)\end{array}$ & $\begin{array}{l}1,307,139(607,653 \\
\text { to } 2,048,820)\end{array}$ \\
\hline
\end{tabular}

NZS = New Zealand dollars; US\$ = United States dollars; UT = urinary tract; SW = surgical wound; CHEST = chest; BS = bloodstream; OTHER = other site; MULTI = multiple sites.

$\$ 251)$ per bed, and $\$ 836$ (US $\$ 377)$ per bed day were $\$ 5,098,242$ (US $\$ 2,300,186$ ), $\$ 10,128,861$ (US $\$ 4,569,862$ ), and $\$ 15,218,374$ (US $\$ 6,866,110$ ), respectively. The total costs for predicted infections in surgical patients assuming $\$ 279$ (US $\$ 126$ ) per bed day, \$557 (US \$251) per bed, and $\$ 836$ (US $\$ 377$ ) per bed day were $\$ 4,297,132$ (US $\$ 1,938,747$ ), $\$ 8,646,190$ (US $\$ 3,900,922$ ), and $\$ 12,928,261$ (US $\$ 5,832,874)$, respectively.

The results of the simulation model for admissions to all hospitals in New Zealand are presented in Table 4.

The total costs for predicted infections in medical patients assuming $\$ 279$ (US \$126) per bed day, $\$ 557$ (US $\$ 251)$ per bed, and $\$ 836$ (US $\$ 377$ ) per bed day were $\$ 25.63$ (US \$11.56) million, \$51.35 (US \$23.16) million, and \$77.15 (US \$34.81) million, respectively. The total costs for predicted infections in surgical patients assuming \$279 (US $\$ 126$ ) per bed day, $\$ 557$ (US \$251) per bed, and $\$ 836$ (US
$\$ 377)$ per bed day were $\$ 42.53$ (US $\$ 19.18$ ) million, $\$ 85.26$ (US $\$ 38.47$ ) million, and $\$ 127.05$ (US $\$ 57.32$ ) million, respectively.

In medical admissions, BS was the most expensive single site of hospital-acquired infection, followed by CHEST, OTHER, SW, and UT. Patients with multiple sites of hospital-acquired infection imposed greater costs than did patients with any single site of hospital-acquired infection. In surgical admissions, SW was the most expensive single site of hospital-acquired infection, followed by UT, CHEST, OTHER, and BS. Patients with multiple sites of hospital-acquired infection incurred costs that were lower than those of patients with SW but higher than those of patients with UT.

The results of the sensitivity analysis are presented in Table 5.

Cost outcomes, with the exception of SW and 
TABLE 4

Mean Cost of Hospttal-AcQuired Infections in Admissions to All Hospitals in New Zealand: Results of Simulation Models FOR THE Three DifFerent VAlUes OF A BeD DAY

\begin{tabular}{|c|c|c|c|c|c|c|}
\hline \multirow{2}{*}{$\begin{array}{l}\text { Hospital- } \\
\text { Acquired } \\
\text { Infection }\end{array}$} & \multicolumn{2}{|c|}{ Low Value of Bed Day (Range) } & \multicolumn{2}{|c|}{ Estlmated Value for Bed Day (Range) } & \multicolumn{2}{|c|}{ High Value for Bed Day (Range) } \\
\hline & Medical & Surgical & Medlcal & Surglcal & Medical & Surglcal \\
\hline \multicolumn{7}{|l|}{ UT } \\
\hline $\mathrm{NZS}$ & $\begin{array}{l}1,403(462 \\
\text { to } 2,853)\end{array}$ & $\begin{array}{l}7,720(6,461 \\
\text { to } 8,873)\end{array}$ & $\begin{array}{l}2,816(959 \\
\text { to } 5,881)\end{array}$ & $\begin{array}{l}15,562(12,940 \\
\text { to } 17,971)\end{array}$ & $\begin{array}{l}4,174(1,380 \\
\text { to } 8,508)\end{array}$ & $\begin{array}{l}23,286(19,465 \\
\text { to } 26,691)\end{array}$ \\
\hline US\$ & $\begin{array}{l}633(208 \\
\text { to } 1,287)\end{array}$ & $\begin{array}{l}3,483(2,915 \\
\text { to } 4,004)\end{array}$ & $\begin{array}{l}1,271(433 \\
\text { to } 2,653)\end{array}$ & $\begin{array}{l}7,021(5,838 \\
\text { to } 8,108)\end{array}$ & $\begin{array}{l}1,883(623 \\
\text { to } 3,839)\end{array}$ & $\begin{array}{l}10,506(8,782 \\
\text { to } 12,042)\end{array}$ \\
\hline \multicolumn{7}{|l|}{ SW } \\
\hline $\mathrm{NZS}$ & $\begin{array}{l}1,773(579 \\
\text { to } 3,048)\end{array}$ & $\begin{array}{l}16,249(10,531 \\
\text { to } 20,709)\end{array}$ & $\begin{array}{l}3,489(1,203 \\
\text { to } 6,290)\end{array}$ & $\begin{array}{l}32,134(21,112 \\
\text { to } 41,260)\end{array}$ & $\begin{array}{l}5,355(1,978 \\
\text { to } 9,404)\end{array}$ & $\begin{array}{l}47,691(31,214 \\
\text { to } 62,337)\end{array}$ \\
\hline US\$ & $\begin{array}{l}800(261 \\
\text { to } 1,375)\end{array}$ & $\begin{array}{l}7,331(4,751 \\
\text { to } 9,343)\end{array}$ & $\begin{array}{l}1,574(543 \\
\text { to } 2,838)\end{array}$ & $\begin{array}{l}14,498(9,525 \\
\text { to } 18,616)\end{array}$ & $\begin{array}{l}2,416(893 \\
\text { to } 4,243)\end{array}$ & $\begin{array}{l}21,517(14,083 \\
\text { to } 28,125)\end{array}$ \\
\hline \multicolumn{7}{|l|}{ CHEST } \\
\hline $\mathrm{NZ} \$$ & $\begin{array}{l}2,942(1,637 \\
\text { to } 4,478)\end{array}$ & $\begin{array}{l}4,291(2,497 \\
\text { to } 6,219)\end{array}$ & $\begin{array}{l}5,992(3,374 \\
\text { to } 9,068)\end{array}$ & $\begin{array}{l}8,555(5,138 \\
\text { to } 12,376)\end{array}$ & $\begin{array}{l}8,882(4,730 \\
\text { to } 13,526)\end{array}$ & $\begin{array}{l}13,040(7,770 \\
\text { to } 18,960)\end{array}$ \\
\hline US\$ & $\begin{array}{l}1,327(738 \\
\text { to } 2,020)\end{array}$ & $\begin{array}{l}1,936(1,127 \\
\text { to } 2,806)\end{array}$ & $\begin{array}{l}2,704(1,522 \\
\text { to } 4,091)\end{array}$ & $\begin{array}{l}3,860(2,318 \\
\text { to } 5,584)\end{array}$ & $\begin{array}{l}4,008(2,134 \\
\text { to } 6,103)\end{array}$ & $\begin{array}{l}5,883(3,506 \\
\text { to } 8,555)\end{array}$ \\
\hline \multicolumn{7}{|l|}{ BS } \\
\hline $\mathrm{NZS}$ & $\begin{array}{l}4,325(844 \\
\text { to } 8,524)\end{array}$ & $\begin{array}{l}1,722(247 \\
\text { to } 4,247)\end{array}$ & $\begin{array}{l}8,438(1,702 \\
\text { to } 16,789)\end{array}$ & $\begin{array}{l}3,500(583 \\
\text { to } 8,374)\end{array}$ & $\begin{array}{l}12,806(2,028 \\
\text { to } 25,280)\end{array}$ & $\begin{array}{l}5,269(617 \\
\text { to } 12,601)\end{array}$ \\
\hline US\$ & $\begin{array}{l}1,951(381 \\
\text { to } 3,846)\end{array}$ & $\begin{array}{l}777(112 \\
\text { to } 1,916)\end{array}$ & $\begin{array}{l}3,807(768 \\
\text { to } 7,575)\end{array}$ & $\begin{array}{l}1,579(263 \\
\text { to } 3,778)\end{array}$ & $\begin{array}{l}5,778(915 \\
\text { to } 11,406)\end{array}$ & $\begin{array}{l}2,377(279 \\
\text { to } 5,685)\end{array}$ \\
\hline \multicolumn{7}{|l|}{ OTHER } \\
\hline NZ\$ & $\begin{array}{l}2,182(382 \\
\text { to } 5,042)\end{array}$ & $\begin{array}{l}2,967(448 \\
\text { to } 6,395)\end{array}$ & $\begin{array}{l}4,549(811 \\
\text { to } 9,708)\end{array}$ & $\begin{array}{l}6,057(902 \\
\text { to } 12,961)\end{array}$ & $\begin{array}{l}6,529(1,199 \\
\text { to } 14,271)\end{array}$ & $\begin{array}{l}8,824(1,452 \\
\text { to } 19,628)\end{array}$ \\
\hline US\$ & $\begin{array}{l}985(172 \\
\text { to } 2,275)\end{array}$ & $\begin{array}{l}1,339(202 \\
\text { to } 2,885)\end{array}$ & $\begin{array}{l}2,052(366 \\
\text { to } 4,380)\end{array}$ & $\begin{array}{l}2,733(407 \\
\text { to } 5,848)\end{array}$ & $\begin{array}{l}2,946(541 \\
\text { to } 6,439)\end{array}$ & $\begin{array}{l}3,981(655 \\
\text { to } 8,856)\end{array}$ \\
\hline \multicolumn{7}{|l|}{ MULTI } \\
\hline NZS & $\begin{array}{l}13,007(8,483 \\
\text { to } 17,574)\end{array}$ & $\begin{array}{l}9,584(4,521 \\
\text { to } 14,962)\end{array}$ & $\begin{array}{l}26,068(17,138 \\
\text { to } 35,064)\end{array}$ & $\begin{array}{l}19,460(9,157 \\
\text { to } 30,739)\end{array}$ & $\begin{array}{l}39,408(26,370 \\
\text { to } 52,231)\end{array}$ & $\begin{array}{l}28,945(13,564 \\
\text { to } 46,698)\end{array}$ \\
\hline US\$ & $\begin{array}{l}5,868(3,827 \\
\text { to } 7,929)\end{array}$ & $\begin{array}{l}4,324(2,040 \\
\text { to } 6,751)\end{array}$ & $\begin{array}{l}11,761(7,732 \\
\text { to } 15,820)\end{array}$ & $\begin{array}{l}8,780(4,132 \\
\text { to } 13,869)\end{array}$ & $\begin{array}{l}17,780(11,898 \\
\text { to } 23,566)\end{array}$ & $\begin{array}{l}13,060(6,120 \\
\text { to } 21,069)\end{array}$ \\
\hline
\end{tabular}

NZS = New Zealand dollars; US\$ United States dollars; UT = urinary tract; SW = surgical wound; CHEST = chest; BS = bloodstream; OTHER = other site; MULTI = multiple sites.

CHEST in medical patients and MULTI in surgical patients, were more sensitive to changes in "prolongation of length of stay" than to changes in the "estimated number of cases."

\section{DISCUSSION}

In the estimation of the local and national costs of hospital-acquired infection, assumptions were made about the values of the number of cases of hospital-acquired infection, the prolongation of the length of stay, and the economic cost of a bed day.

Values for the number of cases of hospital-acquired infection were derived from estimates of the cumulative incidence of hospital-acquired infection in Auckland District Health Board Hospitals and were reported elsewhere. ${ }^{33}$ These were found to be comparable to other reported rates, ${ }^{33}$ and the method used to derive them ${ }^{36}$ has been validated by others. . $^{37,38}$ The total admissions to which these rates were applied, to derive an estimate of the number of cases of hospital-acquired infection, were retrieved from reliable data sources and were assumed to be accurate. It is likely that the estimates of the number of cases are a reasonable approximation to the true values. For the purpose of the simulation modeling, it was assumed that the "most likely" value had a greater probability of occurring than the "low" and "high" values, which had the same probability of occurring. Because these values were derived from the means and $95 \%$ confidence intervals from the predicted cumulative incidence rates, ${ }^{33}$ this assumption is likely to be appropriate.

The assumptions used to determine the prolongation of length of stay are vulnerable to some bias. First, the 
extent to which the results derived from the literature reflect the patient groups included here was not assessed. In particular, values for "all admissions" were used to reflect the prolongation of hospital stay for all predicted cases of hospital-acquired infection in medical patients and for predicted cases of CHEST, BS, and OTHER in surgical patients. Had more specific estimates been available, then these would have been used. Second, the studies used to derive these values employed competing methods for the attribution of additional length of stay to hospital-acquired infection. These methods have been reviewed and found to produce different results when applied to the same patient population..$^{39-42}$ Third, these studies were conducted in different countries and time periods with patients admitted to a range of medical and surgical services. Clinical practice would vary and baseline lengths of stay have certainly changed during the time period in which the studies were conducted. To reduce bias from changes over time, studies whose results were published before 1980 were excluded. Despite these shortcomings, New Zealand is an industrialized country with a gross national product, healthcare system, and life expectancy comparable to those of the countries in which the studies were conducted. We argue that the broad picture of prolongation of hospital stay that emerges from the literature review is transferable to the broad picture in New Zealand, given the caveats already discussed. We also present a range of results that reflect $95 \%$ confidence intervals.

Values for the prolongation of hospital stay due to hospital-acquired infection derived from the literature were treated in the same manner as the number of cases, with the low, median, and high values triangulated for the purpose of the simulation modeling. Nothing could be inferred about the underlying probability distribution of this variable. If more data points were available, goodness of fit tests could have been conducted to determine the nature of the probability distribution. In the absence of this, the approach taken, which used the median and the range of values, was assumed to be optimal.

As a result of variation in both the number of cases and the prolongation of length of stay, the range of results, which reflects $95 \%$ confidence intervals, around the mean cost estimates is wide. Further uncertainty is associated with the estimates of cost for all hospitals in New Zealand, because it was assumed that the cumulative incidence rates derived from the data collection at Auckland District Health Board Hospitals were representative of the rates for the rest of the country.

The method used is an alternative to a specifically designed study with primary data collection. Indeed, to produce the number of results included here by this route would require many years of work and many thousands of research dollars. There appears to be a tradeoff between the precision of results and the research costs.

The valuations of the cost of a bed day are likely to be more robust than the input variables already discussed. They were derived by the administration of Auckland District Health Board Hospitals and reflect local input
TABLE 5

Results of THE SENSITIVITY ANALYSIS: THe EFFECT OF A 1\% CHANGE IN INPUT VARIABles ON COST OUTCOMES*

\begin{tabular}{lcc}
\hline & $\begin{array}{c}\text { Effect of a } \\
\text { 1\% Change In } \\
\text { Prolongation } \\
\text { of Length } \\
\text { of Stay on } \\
\text { Cost Outcome }\end{array}$ & $\begin{array}{c}\text { Effect of a } \\
\text { 1\% Change In } \\
\text { Estimated No. } \\
\text { of Cases on } \\
\text { Cost Outcome }\end{array}$ \\
\hline Cost Outcome & $0.98 \%$ & $0.17 \%$ \\
Cost of UTI in medical & $0.50 \%$ & $0.84 \%$ \\
Cost of SWI in medical & $0.66 \%$ & $0.74 \%$ \\
Cost of CHEST in medical & $0.99 \%$ & $0.11 \%$ \\
Cost of BSI in medical & $0.97 \%$ & $0.22 \%$ \\
Cost of OTHER in medical & $0.85 \%$ & $0.52 \%$ \\
Cost of UTI in surgical & $0.93 \%$ & $0.37 \%$ \\
Cost of SWI in surgical & $0.71 \%$ & $0.68 \%$ \\
Cost of CHEST in surgical & $0.81 \%$ & $0.53 \%$ \\
Cost of BSI in surgical & $0.96 \%$ & $0.25 \%$ \\
Cost of OTHER in surgical & $0.27 \%$ & $0.96 \%$ \\
Cost of MULTI in surgical & & \\
\hline
\end{tabular}

UTI = urinary tract infection; SWI = surgical wound infection; CHEST = chest infection; BSI = bloodstream infection; OTHER = other site of infection; MULTI = multiple sites of infection. *Sensitivity analysis was not possible on MULTI in medical patients because only a point estimate was available for the input variables.

prices and hospital throughput. However, they were not derived explicitly for the purpose of economic analysis, but reflect a monetary valuation of the resources used to supply the bed days. These are subject to certain assumptions about the allocation of jointly used resources, the validity of which has not been tested. A key question is whether these resources have an opportunity cost in their existing use. If they could be re-deployed without cost to supply services to other patients, who have the capacity to benefit and an effective demand, then strong arguments could be made that the resources tied up with the consequences of hospital infection have a marginal economic opportunity cost.

If a proportion of these infections were avoided, the benefits would not accrue as cash savings to the budget statements of the hospital. Instead, bed days would become available sooner for patients who might otherwise be waiting for access to hospital services. This could cause an increase in the costs of the hospital, because patients tend to cost more during the early part of their hospital stay. ${ }^{43}$ However, throughput would most likely increase, driving down the average cost per case as a result of an increase in production efficiency. These are reasonably complex issues, but the key message is that there are likely to be marginal opportunity costs associated with the prolongation of the hospital stay due to hospital-acquired infection because other patients could enjoy benefits if they accessed the bed days sooner and the values presented here are an approximation of those benefits. Also, costs are expressed only in terms of the additional length of stay and not other components of the cost of hospital care. This assumption is 
supported by a recent comprehensive study of the additional costs of hospital-acquired infection that found that $88 \%$ of the additional costs were due to the effects of additional length of stay. ${ }^{34}$

Although these results have face validity, one in particular warrants discussion. The estimated costs of UT infection are much greater for surgical compared with medical admissions. The reason is that the median value for prolongation of length of stay for UT infection in medical patients is only 1 day, compared with 4.7 days for surgical patients (Table 2). These may not be accurate and the reader is encouraged to pay attention to the range of results presented.

The costs reported here are substantial, with the estimates of the total cost of all sites of hospital-acquired infection in all patients admitted to Auckland District Health Board Hospitals close to $\$ 19$ (US \$8.5) million and $\$ 137$ (US \$62) million for all admissions to New Zealand hospitals for calendar year 1999. However, these costs are based on only surgical and medical admissions, which constitute $89 \%$ of adult admissions to all hospitals in New Zealand and $72 \%$ of adult admissions to Auckland District Health Board Hospitals. The remaining admissions are maternity and intensive care patients, for whom the costs of hospital-acquired infection could potentially be great. Also, pediatric admissions were excluded; hospital-acquired infection in this group could also impose significant costs. The costs reported here are likely to understate the total cost.

Only a proportion of hospital-acquired infections are avoidable. An analysis conducted on data collected for the Study of the Efficacy of Nosocomial Infection Control (SENIC) performed in the United States in the 1970s suggested that up to $32 \%$ of hospital-acquired infections could be avoided. ${ }^{44}$ More recent estimates from the United Kingdom put the figure at $15 \%{ }^{45}$ In addition, given that infection control activities have a cost themselves, there must be some comparison of these costs with the economic benefits likely to accrue. From an economist's perspective, the rate of hospital-acquired infection to be tolerated is where the marginal costs of prevention programs are equal with the marginal benefits. This is the point that minimizes the sum of the cost of hospital-acquired infection and the cost of the prevention program. ${ }^{46}$

Work on the cost-effectiveness of prevention programs using either prospective data collection or the modeling of existing data should be a priority for researchers in the area of infection control. A crude analysis of the results presented here suggests that if $10 \%$ of hospital-acquired infections could be avoided, economic benefits to the value of $\$ 1.9$ (US $\$ 0.85$ ) million would accrue to Auckland District Health Board Hospitals and \$13.7 (US \$6.2) million would accrue nationally. If this could be achieved at a cost lower than the available economic benefits, these programs should be pursued.

\section{REFERENCES}

1. Haley RW, Schaberg DR, Crossley KB, Von Allmen SD, McGowan JE Jr. Extra charges and prolongation of stay attributable to nosocomial infections: a prospective interhospital comparison. Am J Med 1981;70:51-58.
2. Rubinstein E, Green M, Modan M, Amit P, Bernstein L, Rubenstein A. The effect of nosocomial infections on the length and costs of hospital stay. J Antimicrob Chemother 1982;9(suppl A):93-100.

3. Scheckler WE. Hospital costs of nosocomial infections: a prospective three-month study in a community hospital. Infect Control 1980;1:150152.

4. Fekerty FR. The epidemiology of infections in surgical patients. In: Control of Infections in Hospitals: Proceedings of an Institute Held at the University of Michigan, March 1-3, 1965. Ann Arbor, MI: University of Michigan School of Public Health; 1965.

5. Kirkland K, Briggs JP, Trivette SL, Wilkinson WE, Sexton DJ. The impact of surgical-site infections in the 1990s: attributable mortality, excess length of hospitalization, and extra costs. Infect Control Hosp Epidemiol 1999;20:725-730.

6. Sperry HE, Craddock J. It pays to spend money for infection control. Modern Hospital 1968;111:124-128.

7. Thoburn R, Fekety FR Jr, Cluff LE, Melvin VB. Infections acquired by hospitalized patients: an analysis of the overall problem. Arch Intern Med 1968;121:1-10.

8. Green M, Rubenstein E, Amit P. Estimating the effects of nosocomial infections on the length of hospitalization. J Infect Dis 1982;145:667-672.

9. Freeman J, Rosner BA, McGowan JE Jr. Adverse effects of nosocomial infection. I Infect Dis 1979;140:732-740.

10. Abramson MA, Sexton DJ. Nosocomial methicillin-resistant and methicillin-susceptible Staphylococcus aureus primary bacteremia: at what costs? Infect Control Hosp Epidemiol 1999;20:408-411.

11. Digiovine $B$, Chenoweth $C$, Watts $C$, Higgins $M$. The attributable mortality and costs of primary nosocomial bloodstream infections in the intensive care unit. Am J Respir Crit Care Med 1999;160:976-981.

12. Rose R, Hunting KJ, Townsend TR, Wenzel RP. Morbidity/mortality and economics of hospital-acquired blood stream infections: a controlled study. South Med J 1977;70:1267-1269.

13. Pittet D, Tarara D, Wenzel RP. Nosocomial bloodstream infection in critically ill patients: excess length of stay, extra costs and attributable mortality. JAMA 1994;271:1598-1601.

14. Spengler RF, Greenough WB. Hospital costs and mortality attributed to nosocomial bacteremias. JAMA 1978;240:2455-2458.

15. Scheckler WE. Septicemia and nosocomial infections in a community hospital. Ann Intern Med 1978;89:754-756.

16. Clarke S. Sepsis in surgical wounds, with particular reference to Staphylococcus aureus, Br J Surg 1957;44:592-596.

17. Coello R, Glenister $H$, Fereres $J$. The cost of infection in surgical patients: a case-control study. J Hosp Infect 1993;25:239-250.

18. Plowman RP, Graves N, Griffin MA. The rate and cost of hospital acquired infections occurring in patients admitted to selected specialties of a district general hospital in England and the national burden imposed. J Hosp Infect 2001;47:198-209.

19. Lowenthal J. Sources and sequelae of surgical sepsis. $B M J 1962 ; 2: 1437-$ 1440.

20. Mugford M, Kingston J, Chalmers I. Reducing the incidence of infection after caesarean section: implications of prophylaxis with antibiotics for hospital resources. BMJ 1989;299:1003-1006.

21. Davies T, Cottingham J. The cost of hospital infection in orthopedic patients. J Infect 1979;1:330-338.

22. Kappstein I, Schulgen G, Fraedrich G, Schlosser V, Schumacher M, Daschner FD. Added hospital stay due to wound infections following cardiac surgery. Thorac Cardiovasc Surg 1992;40:148-151.

23. Schafer U. Cost analysis in nosocomial infections: a 1-year study in the surgical department of Riesa District Hospital [in German]. Zentralbl Chir 1987;112:1552-1560.

24. Poulsen KB, Bremmelgaard A, Sorensen AI, Raahave D, Petersen JV. Estimated costs of postoperative wound infections: a case-control study of marginal hospital and social security costs. Epidemiol Infect 1994;113:282-295.

25. Pena C, Pujol M, Pallares R, et al. Estimation of costs attributable to nosocomial infection: prolongation of hospitalization and calculation of alternative costs. Medicina Clinica 1996;106:441-444.

26. Medina M, Martinez-Gallego G, Sillero-Arenas M, Delgado-Rodriguez M. Risk factors and length of stay attributable to hospital infections of the urinary tract in general surgery patients. Enferm Infecc Microbiol Clin 1997;15:310-314.

27. Li LY, Wang SQ. Economic effects of nosocomial infections in cardiac surgery. J Hosp Infect 1990;16:339-341.

28. Simchen E, Sacks T. Infection in war wounds: experience during the 1973 October War in Israel. Ann Surg 1975;182:754-761.

29. Girard R, Fabry J, Meynet R, Lambert DC, Sepetjan M. Costs of nosocomial infection in a neonatal unit. J Hosp Infect 1983;4:361-366.

30. Haley RW. Cost benefit analysis of infection control activities. In: Brachman P, Bennett V, eds. Hospital Infections. Boston: Little, Brown; 1992:507-532.

31. Plowman RP, Graves N, Roberts JA. Hospital Acquired Infection. London 
Office of Health Economics; 1997.

32. Nicholls TM, Morris AJ. Nosocomial infection in Auckland Healthcare hospitals. $N Z$ Med J 1997;110:314-316.

33. Graves N, Nicholls TM, Wong CGS, Morris AJ. The prevalence and estimates of the cumulative incidence of hospital-acquired infections among patients admitted to Auckland District Health Board Hospitals in New Zealand. Infect Control Hosp Epidemiol 2003;24:56-61.

34. Plowman RP, Graves N, Griffin M, et al. The Socioeconomic Burden of Hospital Acquired Infection. London: Public Health Laboratory Service; 1999.

35. Palisade Corporation. @RISK, Risk Analysis Add-in for Microsoft Excel. New York: Palisade Corp.; 2000.

36. Rhame $F$, Sudderth $W$. Incidence and prevalence as used in the analysis of the occurrence of nosocomial infections. Am J Epidemiol 1981;113:111.

37. Delgado-Rodriguez M. Cueto Espinar A, Rodriguez-Contneras Pelayo R, Galvez Vargas R. A practical application of Rhame and Sudderth's formula on nosocomial infection surveillance. Rev Epidemiol Sante Publique 1987;35:482-487.

38. Gastmeier P, Brauer H, Sohr D, et al. Converting incidence and prevalence data of nosocomial infections: results from eight hospitals. Infect Control Hosp Epidemiol 2001;22:31-34.

39. Asensio A, Torres J. Quantifying excess length of postoperative stay attributable to infections: a comparison of methods. J Clin Epidemiol 1999;52:1249-1256.

40. McGowan JE. Cost and benefit: a critical issue for hospital infection control. Am J Infect Control 1982;10:100-108.
41. Haley RW, Schaberg DR, Von Allmen SD, McGowan JE Jr. Estimating the extra charges and prolongation of hospitalization due to nosocomial infections: a comparison of methods. J Infect Dis 1980;141:248-257.

42. Haley RW. Measuring the costs of nosocomial infections: methods for estimating economic burden on the hospital. Am J Med 1991;91(suppl $3 \mathrm{~B}): 32 \mathrm{~S}-38 \mathrm{~S}$

43. Mellet HM, Harries NS. Costs and the costing process. In: Mellet $\mathrm{H}$, ed. Financial Management in the NHS: A Manager's Handbook. London: Chapman \& Hall; 1993.

44. Haley RW, Culver DH, White JW, et al. The efficacy of infection surveillance and control programs in preventing nosocomial infections in US hospitals. Am I Epidemiol 1985;121:182-205.

45. National Audit Office. The Management and Control of Hospital Acquired Infection in Acute NHS Trusts in England: Executive Summary and Recommendations. London: HMSO; 2000. Available at www.nao.gov.uk/ guidance/chiefexec1c.htm.

46. Graves N. Estimating the Economic Effects of Hospital Acquired Infection [PhD thesis]. London: University of London; 2002.

47. Kappstein I, Schulgen G, Beyer U, et al. Prolongation of stay and extra cost due to ventilator-associated pneumonia in an intensive care unit. Eur J Clin Microbiol Infect Dis 1992;11:504-508.

48. Li LY, Wang SQ. A prospective study of nosocomial infections in cardiac surgery patients in China. Am I Infect Control 1990;18:365-370.

49. Green J, Wenzel RP. Postoperative wound infection: a controlled study of the increased duration of hospital stay and direct cost of hospitalization. Ann Surg 1977;185:264-268.

\section{APPENDIX}

Results of a literature Review to Determine Estimates of the Likely Additional Length of Stay Associated Wrth a Case of URINARY TRACT INFECTION

\begin{tabular}{|c|c|c|c|c|}
\hline Reference & Patlents Studled & $\begin{array}{l}\text { No. of Hospltal. } \\
\text { Acquired Infections } \\
\text { Included In Analysis }\end{array}$ & Country & $\begin{array}{c}\text { Additional } \\
\text { Length of Stay (d) }\end{array}$ \\
\hline Plowman et al., ${ }^{18} 2001$ & All admissions & 107 & England* & 5.1 \\
\hline Haley et al., ${ }^{1} 1981$ & All admissions & 70 & United States $^{\dagger}$ & 1 \\
\hline Haley et al., ${ }^{1} 1981$ & All admissions & 17 & United States $^{\dagger}$ & 0.5 \\
\hline Scheckler, ${ }^{3} 1980$ & All admissions & 38 & United States $^{\dagger}$ & 0.6 \\
\hline Haley et al., ${ }^{1} 1981$ & All admissions & 90 & United States $^{\dagger}$ & 2 \\
\hline Medina et al., ${ }^{26} 1997$ & General surgery & 33 & Spain & 4.7 \\
\hline Rubinstein et al., ${ }^{2} 1982$ & $\begin{array}{l}\text { General surgery and } \\
\text { orthopedics }\end{array}$ & 30 & United States & 5.1 \\
\hline Coello et al., ${ }^{17} 1993$ & $\begin{array}{l}\text { General surgery, } \\
\text { orthopedics, and gynecology }\end{array}$ & 36 & England & 3.6 \\
\hline
\end{tabular}

All studies used matched control subjects for attribution of additional length of stay to hospital-acquired infection, except where * indicates that a cohort study with regression modeling was used and ${ }^{+}$indicates that the concurrent method or physician review was used.

Results of a Literature Review to Determine Estimates of the Likely AdDitional Length of Stay Associated With Multiple SITES OF HOSPITAL-ACQUIRED INFECTION

\begin{tabular}{|c|c|c|c|c|}
\hline Reference & Patlents Studied & $\begin{array}{l}\text { No. of Hospital- } \\
\text { Acquired Infections } \\
\text { Included In Analysis }\end{array}$ & Country & $\begin{array}{c}\text { Additional } \\
\text { Length of Stay (d) }\end{array}$ \\
\hline Plowman et al., ${ }^{18} 2001$ & All admissions & 57 & England* & 29.1 \\
\hline Li et al., ${ }^{48} 1990$ & Cardiac surgery & 43 & China & 25 \\
\hline Rubinstein et al., ${ }^{2} 1982$ & $\begin{array}{l}\text { General surgery and } \\
\text { orthopedics }\end{array}$ & 8 & United States & 18 \\
\hline Coello et al., ${ }^{17} 1993$ & $\begin{array}{l}\text { General surgery, } \\
\text { orthopedics, and gynecology }\end{array}$ & 9 & England & 26.2 \\
\hline
\end{tabular}


Results of a Literature Review to Determine Estimates of the Likely Additional Length of Stay Associated With a Case of CHEST INFECTION

\begin{tabular}{|c|c|c|c|c|}
\hline Reference & Patients Studied & $\begin{array}{l}\text { No. of Hospital- } \\
\text { Acquired Infectlons } \\
\text { Included In Analysis }\end{array}$ & Country & $\begin{array}{c}\text { Addlitlonal } \\
\text { Length of Stay (d) }\end{array}$ \\
\hline Plowman et al., ${ }^{18} 2001$ & All admissions & 48 & England* & 8.4 \\
\hline Freeman et al., ${ }^{9} 1979$ & All admissions ${ }^{\ddagger}$ & 27 & United States & 8.7 \\
\hline Scheckler, ${ }^{3} 1980$ & All admissions & 10 & Untied States & 3.7 \\
\hline Haley et al., ${ }^{1} 1981$ & All admissions & 29 & United States ${ }^{\dagger}$ & 6 \\
\hline Haley et al., ${ }^{1} 1981$ & All admissions & 36 & United States $^{\dagger}$ & 7 \\
\hline Haley et al., ${ }^{1} 1981$ & All admissions & 10 & United States $^{\dagger}$ & 6 \\
\hline Kappstein et al., ${ }^{47} 1992$ & Intensive care c $^{\ddagger}$ & 34 & Germany & 10.13 \\
\hline
\end{tabular}

All studies used matched control subjects for attribution of additional length of stay to hospital-acquired infection, except where * indicates that a cohort study with regression modeling was used, ${ }^{\dagger}$ indicates that the concurrent method or physician review was used, and * indicates that the estimate was not used in modeling presented in this article.

Resutts of a Literature Review to Determine Estimates of the Likely Addtional LeNgth of Stay Associated With a Case of SURGICAL WOUND INFECTION

\begin{tabular}{|c|c|c|c|c|}
\hline Reference & Patlents Studied & $\begin{array}{l}\text { No. of Hospltal- } \\
\text { Acquired Infections } \\
\text { Included In Analysis }\end{array}$ & Country & $\begin{array}{c}\text { Additlonal } \\
\text { Length of Stay (d) }\end{array}$ \\
\hline Plowman et al., ${ }^{18} 2001$ & All admissions & 38 & England* ${ }^{\star}$ & 7.1 \\
\hline Schafer, ${ }^{23} 1987$ & All admissions & 168 & Germany & 11 \\
\hline Pena et al., ${ }^{25} 1996$ & All admissions & 63 & Spain & 10 \\
\hline Haley et al., ${ }^{1} 1981$ & All admissions & 67 & United States $^{\dagger}$ & 8 \\
\hline Haley et al., ${ }^{1} 1981$ & All admissions & 31 & United States $^{\dagger}$ & 7 \\
\hline Haley et al., ${ }^{1} 1981$ & All admissions & 16 & United States ${ }^{\dagger}$ & 4 \\
\hline Scheckler, ${ }^{3} 1980$ & All admissions & 16 & United States $^{\dagger}$ & 7.5 \\
\hline Kappstein et al., ${ }^{47} 1992$ & Cardiac surger $y^{\ddagger}$ & 22 & Germany & 12.2 \\
\hline Poulsen et al., ${ }^{24} 1994$ & General surgery & 291 & Denmark & 5.7 \\
\hline Lowenthal, ${ }^{19} 1962$ & General surgery $y^{\dagger, \S}$ & 177 & England & 7.3 \\
\hline Clarke, ${ }^{16} 1957$ & General surgery ${ }^{*} \S$ & 107 & England ${ }^{\ddagger}$ & 5 \\
\hline Simchen \& Sacks, ${ }^{28} 1975$ & General surgery ${ }^{\ddagger}$ & 94 & Israel & 17 \\
\hline Sperry \& Craddock, ${ }^{6} 1968$ & General surgery $y^{\ddagger}$ & 235 & United States & 15.2 \\
\hline Thoburn et al., 7968 & General surgery $y^{\ddagger \S}$ & 178 & United States ${ }^{\ddagger}$ & 14.1 to 26.3 \\
\hline Fekerty, ${ }^{4} 1965$ & General surgery ${ }^{\ddagger}$ & 143 & United States & 18 \\
\hline Kirkland et al., ${ }^{5} 1999$ & General surgery & 255 & United States & 12 \\
\hline Green \& Wenzel, ${ }^{49} 1977$ & General surgery $y^{\ddagger}$ & 51 & United States & 6 \\
\hline Rubinstein et al., ${ }^{2} 1982$ & $\begin{array}{l}\text { General surgery and } \\
\text { orthopedics }\end{array}$ & 19 & United States & 12.9 \\
\hline Coello et al., ${ }^{17} 1993$ & $\begin{array}{l}\text { General surgery, } \\
\text { orthopedics, and gynecology }\end{array}$ & 12 & England & 10.2 \\
\hline Mugford et al., ${ }^{20} 1989$ & $\begin{array}{l}\text { Maternity-cesarean } \\
\text { sections only }{ }^{\ddagger}\end{array}$ & 41 & England ${ }^{\| t}$ & 2.1 \\
\hline Davies \& Cottingham, ${ }^{21} 1979$ & Orthopedics ${ }^{\ddagger}$ & 29 & England & 17 \\
\hline
\end{tabular}

All studies used matched control subjects for attribution of additional length of stay to hospital-acquired infection, except where * indicates that a cohort study with regression modeling was used, ${ }^{\dagger}$ indicates that the concurrent method or physician review was used, " indicates that the estimate was not used in modeling presented in this article, $\$$ indicates no matching, and "indicates that the study used a retrospective review of 58 controlied trials. 
Results of a Literature Review to Determine estimates of the Likely Additional length of Stay Associated With a Case of BLOODSTREAM INFECTION

\begin{tabular}{|c|c|c|c|c|}
\hline Reference & Patlents Studled & $\begin{array}{l}\text { No. of Hospital- } \\
\text { Acquired Infections } \\
\text { Included In Analysis }\end{array}$ & Country & $\begin{array}{c}\text { Additional } \\
\text { Length of Stay (d) }\end{array}$ \\
\hline Plowman et al., ${ }^{18} 2001$ & All admissions & 4 & England* & 4 \\
\hline Haley et al., ${ }^{1} 1981$ & All admissions & 5 & United States $^{\dagger}$ & 8 \\
\hline Haley et al., ${ }^{1} 1981$ & All admissions & 2 & United States ${ }^{\dagger}$ & 0 \\
\hline Haley et al., ${ }^{1} 1981$ & All admissions & 1 & United States $^{\dagger}$ & 12 \\
\hline Rose et al., ${ }^{12} 1977$ & All admissions & 124 & United States & 32 \\
\hline $\begin{array}{l}\text { Spengler \& Greenough, }{ }^{14} \\
1978\end{array}$ & All admissions & 435 & United States & 14 \\
\hline $\begin{array}{l}\text { Abramson \& Sexton, }{ }^{10} \\
1999\end{array}$ & $\begin{array}{l}\text { All admissions (including } \\
\text { ICU MSSA) }\end{array}$ & 19 & United States & 4 \\
\hline $\begin{array}{l}\text { Abramson \& Sexton, }{ }^{10} \\
1999\end{array}$ & $\begin{array}{l}\text { All admissions (including } \\
\text { ICU MRSA) }\end{array}$ & 19 & United States & 12 \\
\hline Digiovine et al.,11 1999 & Intensive care ca $^{\ddagger}$ & 68 & United States & 7 \\
\hline Pittet et al.," ${ }^{13} 1994$ & Surgical intensive care & 86 & United States & 14 \\
\hline
\end{tabular}

ICU = intensive care unit; MSSA = methicillin-susceptible Staphylococcus aureus; MRSA = methicillin-resistant S. aureus.

All studies used matched control subjects for attribution of additional length of stay to hospital-acquired infection, except where * indicates that a cohort study with regression modeling was used, ${ }^{\dagger}$ indicates that the concurrent method or physician review was used, and *indicates that the estimate was not used in modeling presented in this article.

Restults of a Literature Review to Determine Estimates of the Likely Additional Length of Stay Associated With Other SITES OF INFECTION

\begin{tabular}{|c|c|c|c|c|}
\hline Reference & Patlents Studled & $\begin{array}{l}\text { No. of Hospital- } \\
\text { Acquired Infections } \\
\text { Included in Analysis }\end{array}$ & Country & $\begin{array}{c}\text { Addltional } \\
\text { Length of Stay (d) }\end{array}$ \\
\hline Haley et al., ${ }^{1} 1981$ & All admissions & 20 & United States $^{\dagger}$ & 2.5 \\
\hline Haley et al., ${ }^{1} 1981$ & All admissions & 2 & United States $^{\dagger}$ & 0 \\
\hline Scheckler, ${ }^{15} 1978$ & All admissions ${ }^{\ddagger}$ & 11 & United States $^{\dagger}$ & 5.7 \\
\hline Scheckler, ${ }^{3} 1980$ & All admissions & 15 & United States $^{\dagger}$ & 7 \\
\hline Plowman et al., ${ }^{18} 2001$ & All admissions & 30 & England * & 12.4 \\
\hline
\end{tabular}

All studies used matched control subjects for attribution of additional length of stay to hospital-acquired infection, except where * indicates that a cohort study with regression modeling was used, ${ }^{\dagger}$ indicates that the concurrent method or physician review was used, and * indicates that the estimate was not used in modeling presented in this article. 